\title{
El Medio Ambiente Y Su Influencia En La Literatura De Mahmoud Darwich Y Juan Ramón Jiménez: Estudio Comparativo
}

\section{Ahmad Husein Al-Afif PhD}

The University of Jordan

doi: 10.19044/esj.2016.v12n2p237 URL:http://dx.doi.org/10.19044/esj.2016.v12n2p237

\begin{abstract}
This article is an attempt to make a comparative literary study on the impact of the environment on the poetry of Mahmoud Darwish and Juan Ramon Jimenez. Both of the famous authors treat the issue of the nature, place, time and environment in a wonderful way that gives us the opportunity to study them as special cases even that both poets didn't live in the same period, but in different times. We have chosen some fragments from their poetry as examples of both poets and we found as a conclusion that the two poets have many things in common, especially they way that they deal with the environment and nature.
\end{abstract}

Keywords: Environment, Nature, Homeland, Poetry, Comparative Study

\section{Resumen}

El presente trabajo es un intento de hacer un estudio literario comparativo sobre la repercusión del medio ambiente en la poesía de Mahmoud Darwich y Juan Ramón Jiménez. Ambos célebres autores tratan el tema de la naturaleza, el lugar, el tiempo y el medio ambiente de una forma maravillosa que nos da la oportunidad de estudiarlos como casos extraordinarios a pesar de que no fueron poetas coetáneos, sino que vivieron durante épocas distintas. Hemos elegido algunos ejemplos poéticos de los dos poetas y al final hemos encontrado que los dos poetas tienen cosas comunes, sobre todo en la forma de tratar el medio ambiente y la naturaleza.

Palabras clave: Medio ambiente, naturaleza, patria, poesía, estudio comparativo

\section{Introducción}

El medio ambiente representa uno de los recursos fundamentales de las figuras literarias para los poetas Mahmoud Darwich y Juan Ramón 
Jiménez. En este estudio arrojamos luz sobre algunos ejemplos poéticos de ambos poetas y los ejemplos más destacados en su poesía, donde el medio ambiente se amplía claramente como rasgo común de su poesía nacionalista y popular.

Como es bien sabido, el lugar y la naturaleza representan el medio ambiente que inspiran al poeta para formar sus imágenes y figuras literarias. Este lugar tiene una dimensión muy importante que encarna la relación del ser humano, y es aquí el poeta, con los acontecimientos que suceden en este lugar; dando al mismo tiempo una dimensión estética al texto literario, y dando vida a todas las ideas rígidas de su autor.

\section{La influencia del medio ambiente en el lenguaje y el léxico poético del Diván de Darwich "No te disculpes por lo que hiciste":}

Cuando profundizamos en la poesía de Mahmoud Darwich, y específicamente en su diván "La ta'tader ámma faált" (No te disculpes por lo que hiciste), podemos ver la influencia del medio ambiente en su léxico y lenguaje poético; dicha influencia es el recurso más prominente en las imágenes formadas por el poeta e inspiradas por su formación ideológica y cultural. Darwich utiliza palabras locales del medio ambiente de la tierra Palestina; estas palabras son insustituibles porque si el poeta hubiera utilizado otras palabras que no fueran del medio ambiente local de su tierra natal, el texto no habría tenido el mismo nivel expresivo y estético.

He aquí algunas palabras inspiradas del medio ambiente local:

La piedra: esta palabra la usa Darwich muy frecuentemente en su poesía, pero lo curioso es que la utiliza como símbolo de varios significados, como en este ejemplo cuando dice: "...cada vez escuchaba la piedra oía el arrullo de la paloma"(Darwich, 15). Con esta figura literaria Darwich ha fundado una imagen específicamente relacionada con la causa palestina y su tierra; es la combinación entre el único arma en manos de los palestinos para defender su causa ante sus enemigos israelitas con la paloma que representa la paz.

a. Tanque: esta palabra cotidiana en las calles de Palestina representa el símbolo de la muerte en la poesía de Darwich.

b. Buldócer: también se usa muy frecuentemente en su poesía y tiene un significado negativo relacionado con la muerte y deformación de la bonita naturaleza de Palestina.

Tales palabras usadas en la poesía de Darwich tienen una relación con la búsqueda de la identidad y la muerte. Veremos más tarde la semejanza entre Darwich y Lorca en el uso de estas referencias, que al final llevan a la muerte y el sentido de la pérdida que ambos poetas tenían por motivos políticos y sentimentales. 
En algunas ocasiones, Darwich usa palabras del ambiente pastoril, y otras del campo como el paisaje sembrado de árboles: estas palabras representan el sufrimiento de su autor a la hora de escribir su diván, que sufría en aquel tiempo la nostalgia espiritual.

También cabe mencionar que Darwich utiliza palabras urbanas como: semáforos, asfalto, cocina, autobús, restaurante, taxi, etc...

Existen algunas imágenes compuestas en la poesía de Darwich. En su poema " En la casa de mi madre", la casa representa la casa de su infancia con su familia y, sobre todo, su madre; es la casa de la inocencia. Darwich siempre sentía mucha nostalgia, deseaba volver a vivir en ella y disfrutar los mejores momentos de su infancia. La casa antigua, según Gaston Bachelard es la existencia de un lugar seguro, y podemos vivir estos momentos entre cosas, como ropa, cajones, escaleras y armarios; es el lugar donde sembramos nuestros mejores momentos de la vida (Bachelard: 1992, 12).

Darwichse considera a sí mismo un componente fundamental de esa casa, y creó otro personaje imaginario que todavía está en la casa de su infancia: es una imagen antigua que forma parte del pasado. He aquí un fragmento donde el poeta inicia una conversación con su imagen:

En la casa de mi madre mi retrato me mira

y no deja de preguntarme siempre:

¿es verdad mi huésped que eres yo?

¿tú tenías los veinte años de mi edad,

sin gafas,

ni maletas? (Darwich: 2009, 23)

En otro poema titulado "Tenemos patria", Darwich usa muchas palabras relacionadas con su tierra natal como el lago, la sierra, las colinas, etc....

Darwich ve que la antigua casa, a pesar de estar vacía y abandonada, un hogar donde encontraba mucho cariño y recuerdos de su infancia. Esta casa es el símbolo de su patria "Palestina": la imagen de su tierra natal está llena de contrastes y paradojas, esto es debido al estado de pérdida que siente el poeta por su ausencia durante el exilio. Por este motivo, la casa no pudo recuperarle a sí mismo y a su forma de ser durante su infancia sino que le dejó bloqueado sin reconocer la realidad ni intentar recuperarla.

La imagen del campo es la más brillante en el diván de Mahmoud Darwich, sobre todo las huertas, los árboles y las flores:

...y la ficción se ha abierto

a sus recursos, y se ha hecho lugar,

es el verdadero y el único.

$Y$ todo en lo lejos se vuelve campesino primitivo, yesto parece como si la tierra estuviera formándose 
para recibir a Adán(Darwich: 2009, 45).

Las huertas y las flores en la poesía de Darwich son el eje de sus ideas y no es un complemento ni un adorno: él habla de una tierra que se llena de flores, sobre todo las anémonas cuyo color rojo simboliza la sangre:

Mi amada ha sangrado anémonas, y las rocas del monte se han hecho amarillas

del dolor más cruel del parto, luego se han hecho rojas, y el agua rojo ha corrido, en las venas de nuestra primavera" . (Darwich: 2009, 46)

$\mathrm{Y}$ en otra ocasión en el mismo poema dice:

Por tu desgracia elegiste las huertas

más cercanas de Dios, donde la espada escribe la historia de la arcilla... que los nardos sean tu ejército inmortal, en los campos de trigo, y que los ciervos estén libres como una égloga...(Darwich: 2009, 47).

En su poema " Este es el olvido", Darwich sigue su estado de pérdida y desorientación. La imagen del olvido se relaciona con el tiempo, a través de los elementos del medio ambiente donde vive el poeta, y trata el lugar como base para formar su poema, que une el olvido y la memoria en un bonito contraste, como intento para olvidar algunas cosas del pasado:

Así es el olvido que te rodea: carteles

que despierten el pasado, y le provocan para recordar.

y frenan el tiempo ligero en los semáforos, y cierran las plazas, y luego hizo del olvido una canción:

que persigue la ama de la casa para celebrar

esta ocasión alegre, en la cama y la sala del video

en su salón y cocina (Darwich: 2009, 69'70).

En otro poema titulado "No como hace el turista extranjero" el poeta vuelve a su tierra natal pero como extranjero y turista. Muchos críticos literarios llaman a esta etapa de su vida "la esquizofrenia espiritual"(Darwich: 2009, 134):

Anduve, como hace el turista extranjero, con una cámara, y mi pequeño libro guía, contiene unos poemas que describan este lugar, para más de un poeta extranjero, me siento que soy el único hablante, y si no hubiera tenido diferencias en las rimas hubiera dicho que: yo soy mi otro.(Darwich:2009, 134). 
Vemos que Darwich usa la palabra "extranjero" para hacer referencia a la ausencia de su tierra natal; ha vuelto después de muchos años como el turista extranjero que no reconoce los monumentos del lugar donde pasó los mejores años de su infancia, y para reconocerlos tenía que llevar un libro guía. Esta palabra en realidad es la nostalgia que tiene al pensar en su patria y haciéndole sentir el dolor del exilio.

En los siguientes versos Darwich reconoce su ausencia del lugar que le deja perdido entre unas preguntas:

...Y me he preguntado:¿cómo ve el lugar

el reflejo de su imagen en las leyendas,

o en una de las cualidades del discurso?

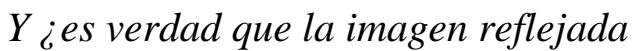

es más fuerte que la cosa misma?

Si no tuviera imaginación, mi otro

me habría dicho que no estoy aquí! (Darwich: 2009, 134).

En los últimos poemas de su diván, Darwich mezcla el lugar y sus elementos, ya habíamos mencionado algunos de ellos, en busca de tierrapatria, donde él, junto con su amigo poeta kurdo Salim Barakat, encuentran refugio para sus sentimientos y sueños:

...No voy a amar la tierra más

o menos que el poema. El kurdo

no tiene más que el viento, que vive

uno en el otro. $Y$ se hacen adictos

uno al otro para salvarse de

las cualidades de la tierra y las cosas...(Darwich: 2009, 169).

Darwich al final concluye su diván con la unión de su amigo kurdo, demostrando su estado de pérdida existencial y desorientación del lugar, a través del uso de los lugares, ambos verdaderos e imaginarios:

Con la lengua tú has vencido la identidad,

dije al kurdo, con la lengua te has vengado

de la ausencia

y él me dijo: no voy a ir al desierto.

Y yo dije: tampoco voy yo.(Darwich:2009, 164).

Vemos que Darwich encarna su filosofía al elegir lo que se puede llamar "no lugar" cuándo le destierre el lugar. Y desde entonces ha empezado su viaje, su nostalgia y búsqueda existencial, y no ha encontrado más que la poesía como el mejor refugio para sustituir su patria e identidad.

\section{El medio ambiente y la naturaleza en la poesía de Juan Ramón Jiménez.}

Juan Ramón Jiménez es uno de los poetas españoles más destacados con su poesía variada, hasta el punto de que los críticos literarios no pueden considerarle poeta de una sola tendencia literaria sino que de varias 
tendencias. Hemos elegido este poeta como ejemplo de los poetas que usan muy frecuentemente las referencias del medio ambiente y la naturaleza por motivos basados en su ausencia de España a causa del estado político inestable durante la primera mitad del siglo XX. Hay muchas semejanzas entre Juan Ramón y Darwich en el sentido de la desorientación y la melancolía aguda cuando hablan de su tierra natal y el medio ambiente al que pertenecen ambos poetas.

Uno de los libros de poesía más representantes del tratamiento de la naturaleza es "Arias tristes", he aquí el siguiente poema:

Entre el velo de la lluvia que pone gris el paisaje, pasan las vacas, volviendo de la dulzura del valle.

Las tristes esquilas suenan

alejadas, y la tarde

va cayendo tristemente sin estrellas ni cantares.

La campiña se ha quedado fría y sola con sus árboles; por las perdidas veredas hoy no volverá ya nadie. Voy a cerrar mi ventana porque si pierdo en el valle mi corazón, quizás quiera morirse con el paisaje. (Juan Ramón Jiménez: 1903, 35)

Juan Ramón Jiménez escribió este poema durante la primera etapa de su vida literaria, llamada la etapa de la inocencia. Esta etapa representa la influencia en Juan Ramón de Gustavo Adolfo Bécquer.

Como vemos en el poema, el poeta se centra en el paisaje y la naturaleza; es un paisaje triste porque las vacas han vuelto del valle a causa de la lluvia que ha cambiado el tiempo y, quizá esta estrofa representa el cambio en la patria que empuja a muchos jóvenes a dejar su tierra en busca de otra vida mejor.

Luego en la siguiente estrofa llega la noche y todo se vuelve oscuro, con el mal tiempo los elementos del paisaje muestran un sentido negativo para el poeta: los campos y los árboles se han quedado solos y los caminos del campo no se ven y cualquiera que llegue al campo estará perdido y desorientado.

Al final, el paisaje, según el poeta, le hace recordar la muerte porque todo en el campo se ha quedado vacío y la gente se ha ido por la llegada de la lluvia y la oscuridad de la noche, porque es una noche sin estrellas. 
En otro poema titulado "Lluvia de otoño", Juan Ramón trata el mismo problema que tenía Darwich al final de su diván, en el sentido de la preocupación existencial, y el sentido del paisaje sin su gente:

LLUVIA DE OTOÑO

(Llueve, llueve dulcemente...)

... El agua lava la yedra;

rompe el agua verdinegra;

el agua lava la piedra...

$Y$ en mi corazón ardiente, llueve, llueve dulcemente

Esté el horizonte triste;

¿el paisaje ya no existe?;

un día rosa persiste

en el pálido poniente...

Llueve, llueve dulcemente.

Mi frente cae en mi mano

¡Ni una mujer, ni un hermano!

¡Mi juventud pasa en vano!

-- Mi mano deja mi frente... --

¡Llueve, llueve dulcemente!

¡Tarde, llueve; tarde, llora;

que, aunque hubiera un sol de aurora

no llegará mi hora

luminosa y floreciente!

¡Llueve, lloradulcemente! (Juan Ramón Jiménez: 1903, 70)

\section{Conclusión}

Podemos decir que Mahmoud Darwich tiene mucha relación con la tierra cuando escribe su poesía, y es una característica compartida con Juan Ramón Jiménez, sin embargo, Darwich niega la vuelta al lugar como patria, porque se lo han quitado los enemigos, y lo sigue buscando en todos los lugares: en el campo, el desierto y la ciudad. La preocupación existencial es un rasgo común entre ambos poetas y hablan en su poesía sobre su separación espiritual que lleva a la separación del tiempo y el lugar. También ambos poetas usan los símbolos frecuentemente para hablar de la patria y sus elementos.

\section{References:}

Bachelard, Gaston. La poética del espacio: Fundo de Cultura Económica. México. 2012.

Cortés, Julio, Diccionario de árabe culto moderno: árabe-español. Gredos, Madrid. 1996. 
Darwich, Mahmoud. La ta'tader ámma faált: Dar Riyad Al-Rayyes. Beirut. 2009.

\section{References consultadas:}

Alarcón Sierra, Rafael. Juan Ramón Jiménez: pasión perfecta. Espasa Calpe. Madrid. 2003.

Estudios de Asia y Africa. El Colegio de México. México. 2003.

Naasar, Hala Khamis, Rahman, Najat. Mahmoud Darwush Exile's Poet. Olive Branch Press. 2008.

Poesía árabe.com. Mahmud Darwish. Madrid. 2002.

http://www.poesiaarabe.com/mahmud\%20darwish.htm

Ramón Jiménez, Juan. Antología Comentada. Ediciones de la Torre. Madrid. 1986. 